\title{
Characterisation of groundwater-surface water interaction using field measurements and numerical modelling: a case study from the Ruataniwha Basin, Hawke's Bay, New Zealand
}

\author{
Husam Musa Baalousha
}

Received: 11 April 2011 / Accepted: 2 February 2012/Published online: 18 February 2012

(C) The Author(s) 2012. This article is published with open access at Springerlink.com

\begin{abstract}
Shallow aquifer systems overlain by rivers constitute normally one hydrogeological entity, because of the interconnection between aquifers and surface water. On the one hand, groundwater abstraction in such aquifer systems may deplete streams. On the other hand, overexploitation of surface water may result in a drop in groundwater level and adverse effects on the environment. It is important, therefore, to understand the relation between rivers and aquifers and to quantify the loss-gain relationship between them. This will help establishing a better water resources management and to reduce or prevent impacts on the environment. In this study, historical rivers flow data in the Ruataniwha Basin in New Zealand has been used to simulate groundwater-surface water, using the finite difference-based MODFLOW model. The model results were checked against six runs of recent concurrent gauging covering the whole basin. The numerical model results show that rivers and aquifers relation varies spatially from one location to another. Quantitatively, rivers gain from the aquifer system much more than what they lose. These results are consistent with the concurrent gauging data.
\end{abstract}

Keywords Groundwater-surface water interaction . Numerical modelling · Ruataniwha Basin . Concurrent gauging $\cdot$ Stream routing

H. M. Baalousha ( ()

Hawke's Bay Regional Council, 159 Dalton Street,

Napier 4110, New Zealand

e-mail: Baalousha@web.de

\section{Introduction}

Groundwater and surface water are the main sources of water supply for agriculture, industrial and domestic use. As part of the hydrological cycle, both groundwater and surface water are interconnected. Understanding the loss/ gain relationship between aquifers and surface water is important, especially in sensitive catchments, where high pumping of groundwater resulted in severe decline in nearby surface waters, threatening the ecosystem and the overall water balance.

Traditionally, people manage groundwater and surface water separately. This approach proved to be invalid, as both groundwater and surface water affecting each other, and thus, should be treated as one entity (Winter et al. 1998).

Groundwater and surface water resources are interconnected in many ways. Heavy pumping of groundwater, for example, may deplete a nearby stream. Surface water contamination may seep into the aquifers resulting in groundwater contamination.

Many approaches can be used to understand the groundwater and surface water relationship in a catchment. One approach, which has widely been used, is the thermal records change in the riverbed. In this approach, heat is used as a seepage tracer (Lapham 1989; Anderson 2005; Lowry et al. 2007; Hatch et al. 2006; Barlow and Coupe 2009). This method has been used to understand the groundwater movement and gain/loss relationship between rivers and aquifers by monitoring the temperature fluctuation in the streambed (Constantz 2008). The problem of this approach is that it is not easy to set and operate temperature monitoring devices in the streambed environment (Constantz 2008). In addition, it is difficult to use this approach on a catchment scale, as the gain-loss relationship may change frequently from one location to another. 
Another approach is based on ion chemistry. In this approach, statistical analysis of major ions in groundwater and surface water over a long time is used to understand this relation (Kumar et al. 2009). This approach has many limitations, especially in complex catchments where the groundwater-surface water interaction is high. The major ion chemistry may fail to capture the fast change in gain/ loss relationship, and the water chemistry may need a long time to change. As the groundwater movement is generally slow, movement of groundwater to surface water (or the other way) does not mean moving the same molecules of water from one location to another. It is the propagation of the effects of groundwater abstraction or rivers flow change that creates the gain/loss.

Other studies combined isotopes analysis with chemistry to better understand the river/aquifer interaction (Négrel et al. 2003; Gooddy et al. 2006; Ayenew et al. 2008). In addition to the expenses of the analysis, this approach requires a time series of isotopes analysis to avoid ambiguity, which increases the expenses.

Numerical modelling has widely been used in this context (Krause et al. 2007; Parkin et al. 2007; Rassam et al. 2008). Numerical modelling is a good and cheap method for understanding water systems, but requires a lot of data and good calibration to be used for management.

In this study, groundwater-surface water numerical modelling has been used to understand and to quantify the gain-loss relationship between rivers and aquifers in the Ruataniwha Basin, Hawke's Bay, New Zealand. Rivers' gauging data covering more than 20 years have been used in this study. A recent concurrent gauging has been undertaken to support and to validate the numerical modelling. The finite difference-based MODFLOW model (McDonald and Harbaugh 1988) has been used to build a transient groundwater model, and the Stream Package in MODFLOW (STR) has been used for stream routing. The model simulation period extends for the period from 1990 to 2010. Model flow results have been compared with historical field measurements, and checked against the recent concurrent gauging.

\section{The study area and geology}

Ruataniwha Basin is one of the main sources of water supply for irrigation, industry and domestic use. The basin is located in the southern part of the Hawke's Bay region in the North Island of New Zealand (Fig. 1).

The surface catchment of the Ruataniwha is bounded by Manawatu Region in the south, by foothills of the Ruahine Range in the west, Turiri Range and Raukawa Range in the east and rolling hills in the north. The total area of the surface catchment is $1,472 \mathrm{~km}^{2}$, whereas the basin area is $\sim 800 \mathrm{~km}^{2}$.

Three main rivers and streams traverse the basin from west to east: Waipawa River in the north, Tukituki River in the middle and Makaretu Stream in the south (see Fig. 1), in addition to smaller streams. Tukituki River and Makaretu Stream meet just before leaving the basin. The Waipawa and the Tukituki River meet out of the basin, a few kilometres to the east of Waipawa and Waipukurau townships.

Over the last decade, agricultural activities in the study area have intensified, which posed high stresses on water resources in the basin. The ecosystem of the basin is regularly placed at risk as some stream reaches and springs dry during summer peak demand, pursuant to extended drought period and high groundwater abstraction.

The geology of the basin comprises sequences of alluvial gravel from Quaternary period with intermittent clay layers of variable thicknesses and the more consolidated gravel deposits (i.e. Salisbury Gravel) from the Pleistocene. Two main gravel layers occur in the basin: the Young Gravel at the top and Salisbury Gravel underneath. The Young Gravel is unconsolidated and contains clay, silt and volcanic ash of late Quaternary (Francis 2001). This layer occurs close to the surface, and it is more permeable than Salisbury Gravel layer underneath. The Salisbury Gravel is composed of slightly to poorly consolidated gravel, ignimbrite and clay from the lower Quaternary (Francis 2001). The total thickness of gravel layers varies from a few metres at the west to $\sim 200 \mathrm{~m}$ in the middle of the basin. The basin is closed in terms of hydrogeology, i.e. no lateral groundwater flows in or out of the basin. The groundwater flows in the basin from the north-west to the south-east direction. The main water inflow into the basin is through the Waipawa, the Makeretu and the Tukituki rivers, in addition to rainfall within the basin. The outflow is through the Waipawa and the Tukituki rivers in the east. Annual rainfall over the basin varies from $900 \mathrm{~mm}$ in the east to more than $1,300 \mathrm{~mm}$ in the west.

\section{Materials and methods}

\section{Concurrent rivers gauging}

A total number of seven concurrent gauging runs have been carried out over the 2008/2009 summer. A total of 30 gauging sites on 12 rivers and streams have been selected (Fig. 1). Selection of gauging sites was based on historical gauging sites, and considering the possible changes in rivers gain-loss relations with aquifers. The important rivers and streams have closely-placed gauges, while the 
Fig. 1 The study area, geology, model boundaries and river gauging sites

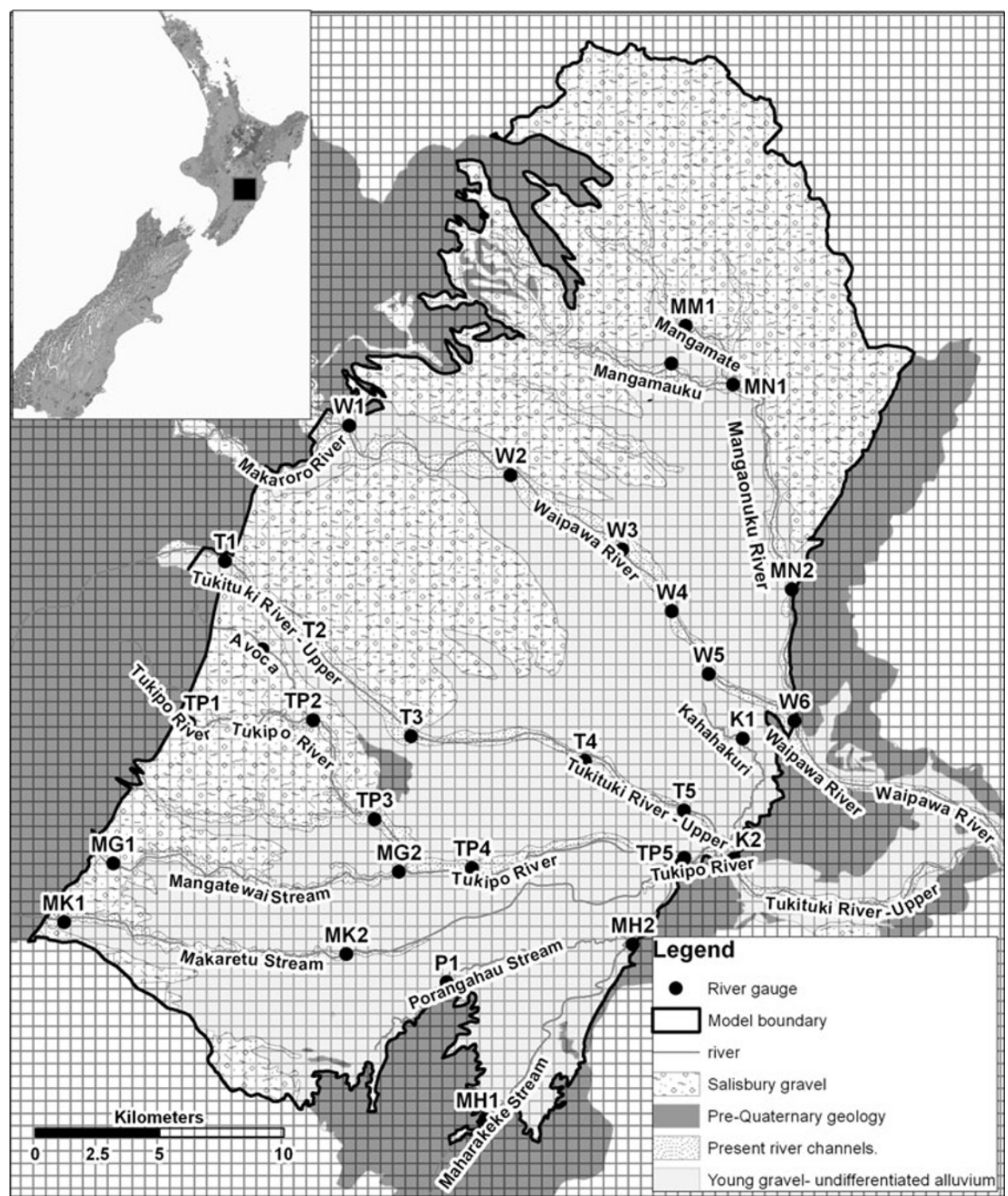

smaller streams have a fewer number of gauges. Table 1 lists the gauging sites at rivers and streams.

The field work was aimed at gauging a range of flows across the hydrograph in an effort to establish robust flow correlations. Rivers' levels were monitored using telemetered flow sites and target flows were set for subsequent survey runs. It was important to concentrate on low flows, especially in the known drying reaches. A total of seven concurrent gauging runs have been carried out at all gauging sites (Fig. 1) for the time from December 2008 to June 2009.

Numerical conceptual model and stream routing

The model domain comprises the Young and Salisbury Gravel Formations (Fig. 1), covering an area of $\sim 800 \mathrm{~km}^{2}$. The domain was discretized into a $500 \times 500 \mathrm{~m}$ finite difference grid, resulting in a mesh of 97 rows and 83 columns. The finite difference-based MODFLOW model, with Stream Package, has been used to build a transient model for the area, within the Visual MODFLOW environment (Schlumberger Water Services 2008). The simulation period spans the time from 1990 until 2010, using 70 stress periods.

The model boundaries (Fig. 1) were delineated based on the hydrogeology. The model has no flow boundaries, as no lateral groundwater flow enters or leaves the basin. Inflows into the basin include rainfall over the basin and rivers inflow upstream at the western side of the basin. Outflows are groundwater pumping and groundwater seepage to rivers, which exit the basin in the east. This study will focus on the groundwater-surface water interaction, and not on other model aspects. Full details of the model can be found in Baalousha (2010). 
Table 1 Rivers/streams gauging sites

\begin{tabular}{|c|c|c|}
\hline Number & Gauge & River/stream name \\
\hline 1 & W1 & Waipawa \\
\hline 2 & W2 & Waipawa \\
\hline 3 & W3 & Waipawa \\
\hline 4 & W4 & Waipawa \\
\hline 5 & W5 & Waipawa \\
\hline 6 & W6 & Waipawa \\
\hline 7 & $\mathrm{~T} 1$ & Tukituki \\
\hline 8 & $\mathrm{~T} 2$ & Tukituki \\
\hline 9 & $\mathrm{~T} 3$ & Tukituki \\
\hline 10 & $\mathrm{~T} 4$ & Tukituki \\
\hline 11 & T5 & Tukituki \\
\hline 12 & T6 & Tukituki \\
\hline 13 & MM1 & Mangamate \\
\hline 14 & MU1 & Mangamauku \\
\hline 15 & MN1 & Mangaonuku \\
\hline 16 & MN2 & Mangaonuku \\
\hline 17 & K1 & Kahahakuri \\
\hline 18 & A1 & Avoca \\
\hline 19 & MH1 & Maharakeke \\
\hline 20 & MH2 & Maharakeke \\
\hline 21 & $\mathrm{P} 1$ & Porangahau \\
\hline 22 & MK1 & Makaretu \\
\hline 23 & MK2 & Makaretu \\
\hline 24 & MK3 & Makaretu \\
\hline 25 & MG1 & Mangatewai \\
\hline 26 & MG2 & Mangatewai \\
\hline 27 & TP1 & Tukipo \\
\hline 28 & TP2 & Tukipo \\
\hline 29 & TP3 & Tukipo \\
\hline 30 & TP4 & Tukipo \\
\hline
\end{tabular}

The flow $(q)$ between a stream and the aquifer, using the Stream Package of MODFLOW (SFR1) is based on Darcy Law, is given as:

$q=C W \frac{h_{\mathrm{st}}-h_{\mathrm{gr}}}{M}$

where $C$ is the hydraulic conductivity of the streambed, $W$ is the width of the stream. $M$ is the thickness of the streambed, $h_{\mathrm{st}}$ is the water level (head) in the stream and $h_{\mathrm{gr}}$ is the groundwater head next to the stream. When the head in the stream $\left(h_{\mathrm{st}}\right)$ is higher than the head in the aquifer, stream loses water to the aquifer, and when the head in the stream is less than the head in the aquifer, the stream gains water. If the head in the aquifer falls below the streambed bottom, the stream loss rate becomes constant.

Streams and rivers in the study area have been divided into segments. Each segment connects between two gauging sites (Fig. 1). A total number of 28 segments
Table 2 Segments within the study area

\begin{tabular}{|c|c|c|c|}
\hline Segment & River & From & To \\
\hline S1 & Waipawa & W1 & W2 \\
\hline $\mathrm{S} 2$ & Waipawa & W2 & W3 \\
\hline S3 & Waipawa & W3 & W4 \\
\hline S4 & Waipawa & W4 & W5 \\
\hline S5 & Waipawa & W5 & W6 \\
\hline S6 & Mangamauku & MU1 & MN1 \\
\hline S7 & Mangamate & MM1 & MN1 \\
\hline S8 & Mangaonuku & MN1 & MN2 \\
\hline S9 & Mangaonuku & MN2 & W6 \\
\hline $\mathrm{S} 10$ & Tukituki & $\mathrm{T} 1$ & $\mathrm{~T} 2$ \\
\hline S11 & Tukituki & $\mathrm{T} 2$ & T3 \\
\hline S12 & Tukituki & T3 & $\mathrm{T} 4$ \\
\hline S13 & Tukituki & $\mathrm{T} 4$ & T5 \\
\hline S14 & Tukituki & T5 & T6 \\
\hline S15 & Makaretu & MK1 & MK2 \\
\hline S16 & Makaretu & MK2 & MK3 \\
\hline S17 & Kahahakuri & K1 & $\mathrm{T} 6 / \mathrm{K} 2$ \\
\hline S18 & Tukipo & TP1 & TP2 \\
\hline S19 & Mangatewai & MG1 & MG2 \\
\hline S20 & Avoca & A1 & TP2 \\
\hline S21 & Tukipo & TP2 & TP3 \\
\hline S22 & Tukipo & TP3 & MG2 \\
\hline S23 & Tukipo & MG2 & TP4 \\
\hline S24 & Tukipo & TP4 & MK3/TP5 \\
\hline S25 & Tukipo & MK3/TP5 & T6 \\
\hline S26 & Porangahau & $\mathrm{P} 1$ & MH2 \\
\hline S27 & Maharakeke & MH1 & MH2 \\
\hline S28 & Maharakeke & MH2 & MK3 \\
\hline
\end{tabular}

forming 12 rivers and streams resulted. Table 2 lists the segments, start and end points. Each segment crosses a number of model cells, and each cell where the segment crosses is called a reach.

The surface flow modelling (or the stream routing in MODFLOW) considers the stream flow budget. The total inflow into a reach may be written as (Prudic et al. 2004):

$\sum Q_{\text {in }}=Q_{\text {sri }}+Q_{\text {trb }}+Q_{\mathrm{ro}}+Q_{\mathrm{ppt}}-Q_{\mathrm{Li}}$

where $Q_{\text {in }}$ is the total inflow into a reach, $Q_{\text {sri }}$ is the specified flow at the first reach of a segment, $Q_{\text {trb }}$ is the sum of tributary flow from upstream segments into the first reach of a segment, $Q_{\mathrm{ro}}$ is the direct overland runoff to a reach (if any), $Q_{\mathrm{ppt}}$ is the precipitation that falls directly on a reach and $Q_{\mathrm{Li}}$ is the groundwater leakage to a reach calculated by the model (Eq. 1).

The last component of Eq. 2 has a negative sign because for MODFLOW groundwater model, it means that the aquifer loses if the stream gains. 
Similarly, the outflow from a reach is given by (Prudic et al. 2004):

$\sum Q_{\mathrm{out}}=Q_{\mathrm{sro}}+Q_{\mathrm{div}}+Q_{\mathrm{et}}+Q_{\mathrm{Lo}}$

where $Q_{\text {out }}$ is the total outflow of a reach, $Q_{\text {sro }}$ is the stream flow out of a reach, $Q_{\text {div }}$ is the specified diversions from the last reach in a segment, $Q_{\text {ro }}$ is the direct overland runoff to a reach (if any) and $Q_{\text {et }}$ is the evapotranspiration from a reach.

The last term in Eq. 3 is used only when the stream is losing water to the aquifer (input into the aquifer, so it has a positive sign).

For each time step, the model computes the head in the river and in the groundwater in a reach. Accordingly, the flow given by Eq. 1 can be positive or negative. In the meantime, the model computes surface water flow based on Eqs. 2 and 3.

The required data for stream routing includes the historical data of stream flows at each gauging point as shown in Fig. 1, in addition to the streambed elevation, streambed thickness and surface water level at each stress period. This data has been obtained from the Hydrology Database at the Hawke's Bay Regional Council for the period between 1990 and 2010.

\section{Surface water budget}

The main water inflow into the system occurs at points $\mathrm{W} 1$, T1 and MK1 as shown in Fig. 1. These points are located just at the upper boundaries of the basin, and constitute the main river entry points. The average annual flow upstream of each river and stream is shown in Table 3.

The surface outflow of the basin takes place at W6 and T6 points via Waipawa and Tukituki rivers (Fig. 1). The combined outflow of upper Waipawa and Mangaonuku forms the Waipawa River just at the eastern edge of the basin. The upper Tukituki and the Tukipo rivers meet to

Table 3 Average annual surface water inflow upstream (based on 20 years data)

\begin{tabular}{lc}
\hline River or stream & Average annual flow $\left(\right.$ million $\left.\mathrm{m}^{3}\right)$ \\
\hline Tukituki & 126.9 \\
Waipawa & 264.1 \\
Avoca & 9.4 \\
Tukipo & 11.6 \\
Mangatewai & 27.8 \\
Makaretu & 40.9 \\
Porangahau & 12.9 \\
Maharakeke & 10.3 \\
Total & 503.9 \\
\hline
\end{tabular}

form the Tukituki River. The average total annual surface water outflow at W6 and T6 is $\sim 725$ million $\mathrm{m}^{3}$.

\section{Model result and concurrent gauging}

The average summer and winter flow for the period from 1990 to 2010 has been input into the SFR1. Only first reaches of first segments have assigned measured flow data. These points are from north to south MM1, MU1, W1, T1, A1, K1, TP1, MG1, MK1, P1 and MH1. The remaining gauging points have not been assigned flow values as the model performs stream routing and calculates the interaction between rivers and aquifers.

Numerical model results include the flow at each reach along each river and river losses or gains to and from groundwater. The error in gauging measurements is $\pm 8 \%$ of the flow. Figure 2 shows the simulated river outflow at the edge of the basin at points $\mathrm{W} 6$ and $\mathrm{T} 6$, and the upper and lower bound of measured flow (flow $\pm 8 \%$ ). Obviously, the simulated flows at both W6 and T6 occur between the upper and lower limits of gauging errors, except at three points in the $\mathrm{W} 6$ time series. Correlation analysis between the simulated and measured time series is 0.987 and 0.983 at W6 and T6, respectively.

In addition to correlation analysis, the root mean square error (RMSE) between the numerical results and the measured time series has been calculated. It was found that the RMSE are 13 and $15 \%$ of the mean measured flow at T6 and W6, respectively. Knowing that the gauging error is $\pm 8 \%$, the RMSE values are acceptable.

The spatial distribution of gain and loss between rivers and aquifers is shown in Fig. 3. The rate of gain and loss is expressed in the figure in a form of bars along rivers and streams. In Fig. 3, the white bars indicate river gain, and the black bars indicate river loss. The bar height is proportional to the loss/gain rate.

Figure 3 shows that rivers gain and lose at different locations in the basin, but in terms of volume the rivers' gain is more than the loss. Rivers and streams are mainly stable in the upper part of the basin (upstream), and they gain as they approach the basin exit to the east. Some rivers, however, behave in a different way.

The Mangaonuku River, in the northern side of the basin gains water from the aquifer all along its course. The Waipawa River starts gaining upstream and then loses until it meets Mangaonuku stream.

Tukituki River behaves in a similar way as Waipawa River, while Tukipo River gains all the way along its course. The smaller streams in the south start losing upstream and then gaining as they approach the Tukipo and Makaretu confluence.

The volumetric surface water budget components resulting from the numerical model are shown in 
Fig. 2 Measured and simulated flow time series at W6 and T6

\section{Measured and Simulated flow at W6}

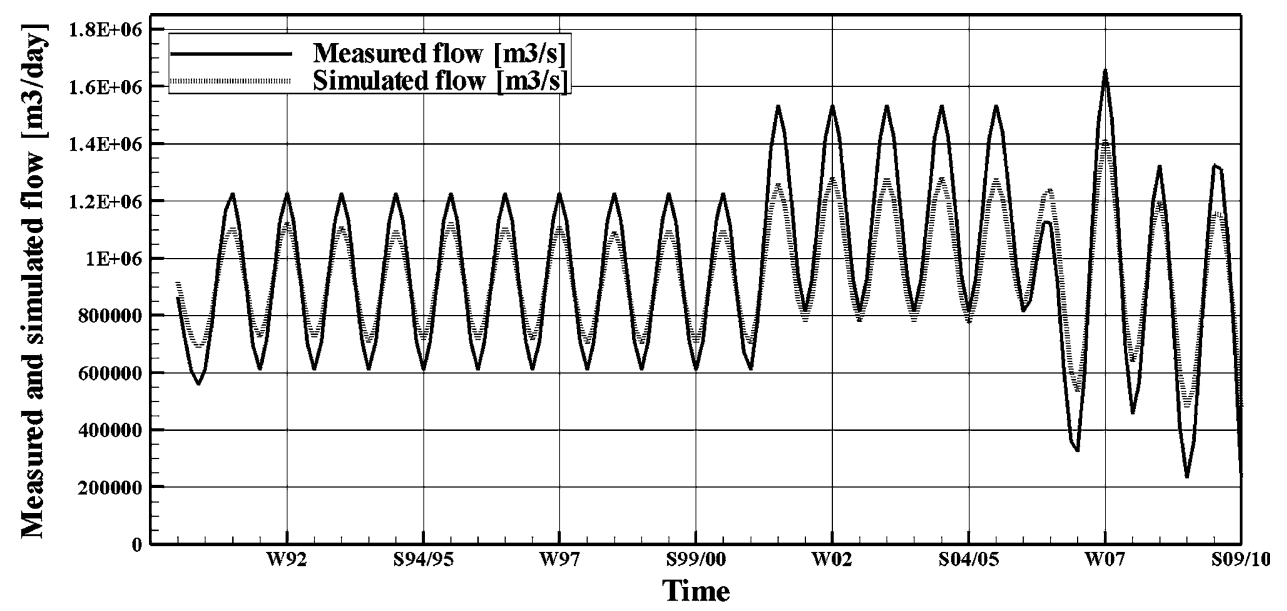

Measured and Simulated flow at T6

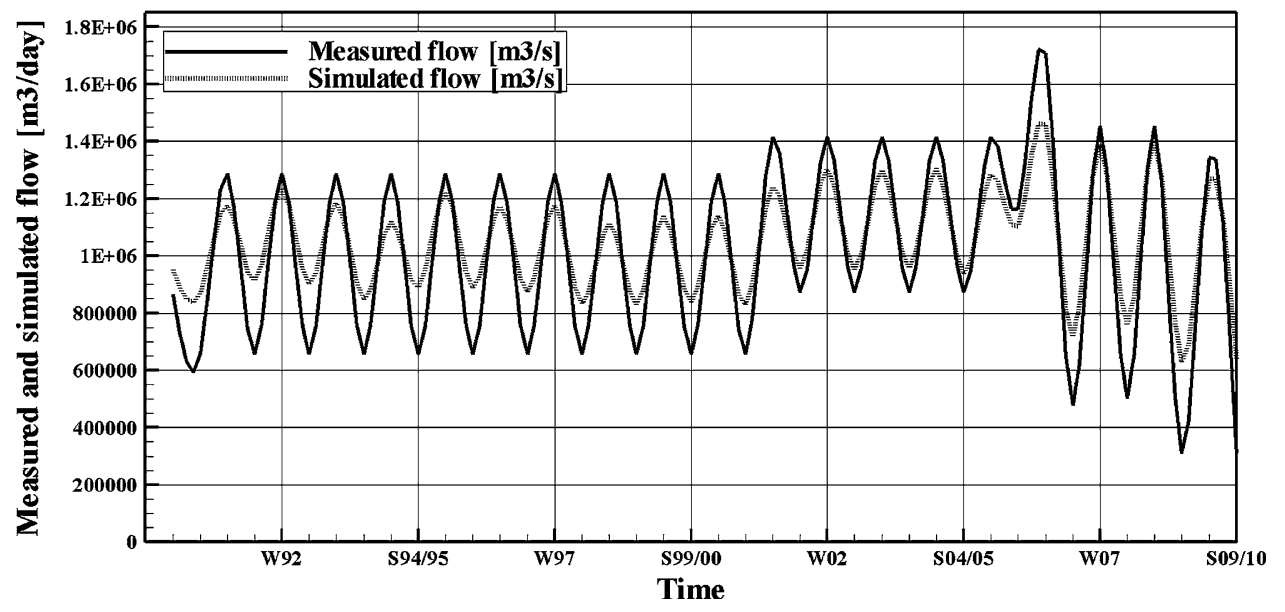

Table 4, along with measured data. The surface water balance may be computed based on the following equation:

$R_{\text {out }}=R_{\text {in }}-R_{\text {loss }}+R_{\text {gain }}-S$

where $R_{\text {out }}$ is the total rivers' outflow, $R_{\text {in }}$ is the total rivers inflow, $R_{\text {loss }}$ is the river losses to the groundwater system, $R_{\text {gain }}$ is the rivers gain from the groundwater system and $S$ is the surface water takes.

The volume of surface water takes has been approximated based on water consent data obtained from the Hawke's Bay Regional Council.

Data in Table (4) shows that the river outflow volume is close to the measured value. This has also been confirmed with the very good correlation between simulated and measured flows at W6 and T6 (Fig. 2). The discrepancy in the average annual outflow between measured and simulated is $0.1 \%$, which is very small.

Equation (4) can be used to check the validity of surface water balance resulting from the model. Using Eq. 4, the total outflow is 707 million $\mathrm{m}^{3} /$ year. The discrepancy in water surface budget is $1.5 \%$, which is much less than the gauging error, which is $8 \%$.

In addition to water budget, the numerical model produced the groundwater head contour map (Fig. 4) and the particle tracking map (Fig. 5). The latter map is a result of placing particles within the model domain and tracking their movement by advection over time. It helps understanding the path-lines of water particles and the fate of water within the model domain.

The concurrent gauging results help understanding the gain-loss pattern between groundwater and rivers in the basin, but it does not help with qualitative analysis of flow, as it was undertaken in summer time only.

\section{Mangaonuku River}

Monitoring of flow in Mangaonuku River shows that the flow increases from upstream to downstream. The river starts at low or dry reaches upstream and increases to its maximum just before it meets the Waipawa River. This is consistent with the model results shown in Fig. 3. 
Fig. 3 Rivers/aquifers relationship based on numerical modelling

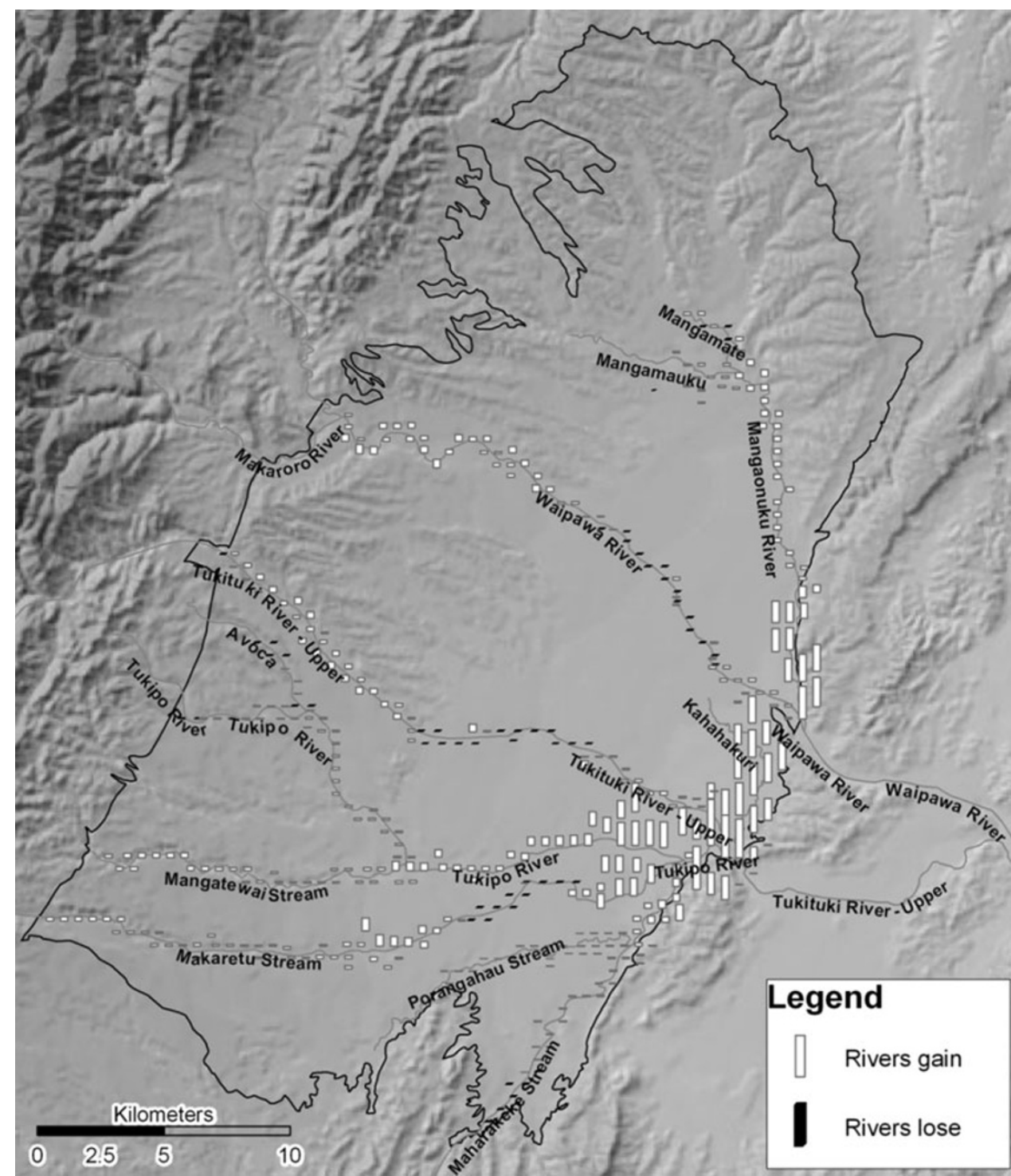

Concurrent gauging data indicates that flow upstream between the Makaroro confluence W2 (Fig. 1) is predominantly conservative. The river starts losing at W2 and has dry reach at the lower end during peak summer abstraction. The model results (Fig. 3) show the Waipawa River gains upstream at lower rates, and then start losing to the Waipawa-Mangaonuku confluence. This is also clear in the groundwater head and velocity map shown in Figure (4) as the flow lines in the lower Waipawa moves towards Kahahakuri Stream and Mangaonuku River. The particle tracking map (Fig. 5) shows flow paths moving from upper Waipawa towards Kahahakuri Stream.

\section{Kahahakuri Stream}

The Kahahakuri Stream gains $100 \%$ of its flow from the groundwater, and shows a steady base flow in the lower reach (Hawke's Bay Regional Council 2003). It is believed recorded lengths of the drying reach approaching $8 \mathrm{~km}$. 
Fig. 4 Groundwater head contour map and velocity vectors

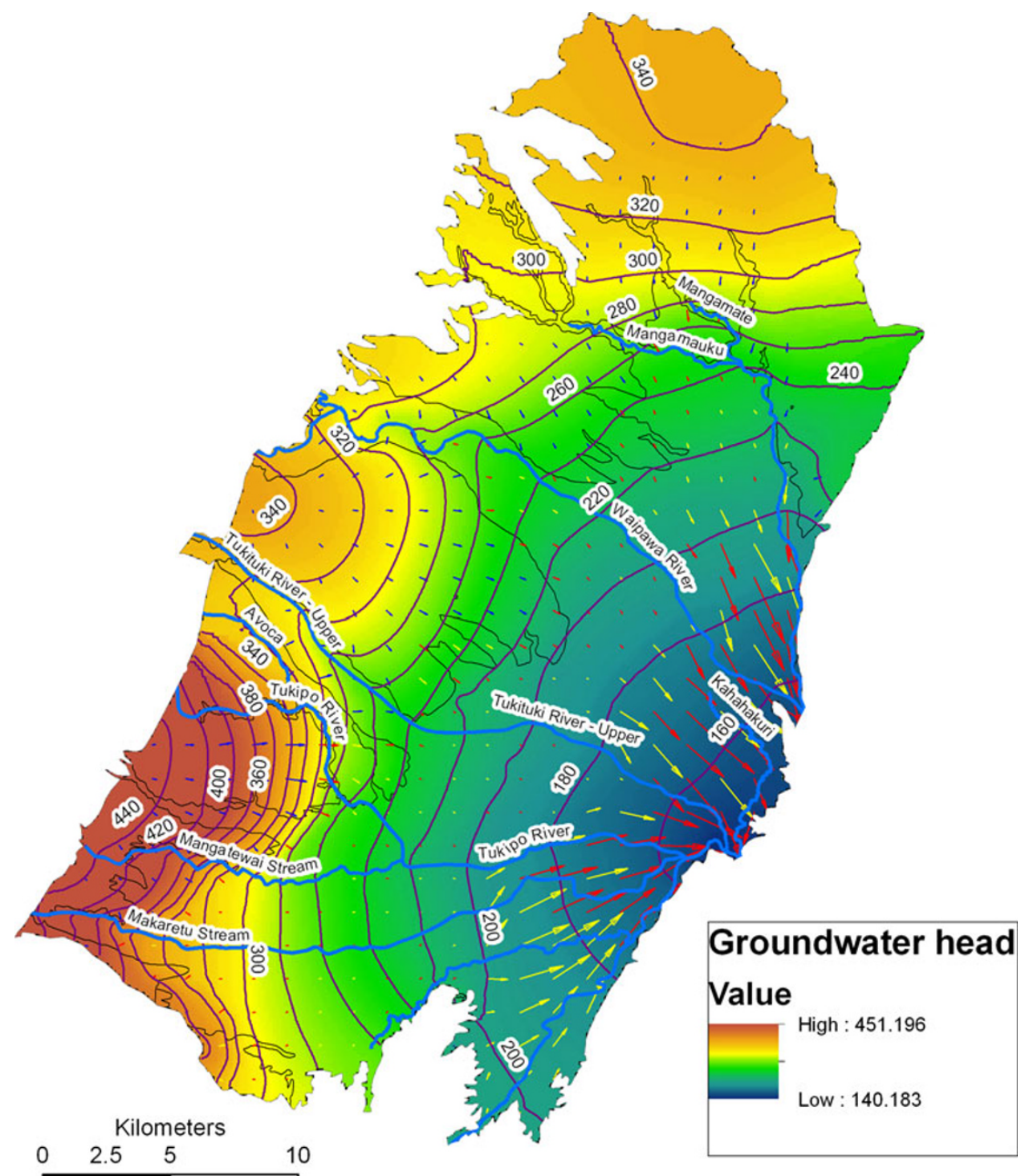

that losses from the Waipawa River are being captured by this stream. These results are confirmed by recent isotopes study carried out in the area. The upper Kahahakuri Stream area seems to be a discharge area, as shown by the particle tracking analysis (Fig. 5). Figure (4) shows the groundwater head contours and the flow direction. In the lower Waipawa River, flow lines moves towards Kahahakuri Stream and seeps out as springs that feed the stream.

\section{Tukituki River}

The Tukituki River has a similar behaviour to the Waipawa River but at a smaller scale. The flow is stable upstream, and the river loses downstream. Unlike the Waipawa River, the groundwater velocity lines (Fig. 4) shows flow lines going away from the lower Tukituki. This means that the lower Tukituki is losing water.

\section{Tukipo River}

Gauging data across several studies show that the Tukipo is a predominantly gaining stream along its length. Some studies have identified short sections of the river that lose flow, but with an overall gain at the confluence. The most recent concurrent gauging data show consistent gaining conditions between all gauging sites. The particle tracking (Fig. 5) shows that the flow lines end in the lower Tukipo, which confirms that it is gaining.

Model results show that the Tukipo River is gaining, with increasing gain in the downstream direction. The 
Fig. 5 Particle tracking flow paths

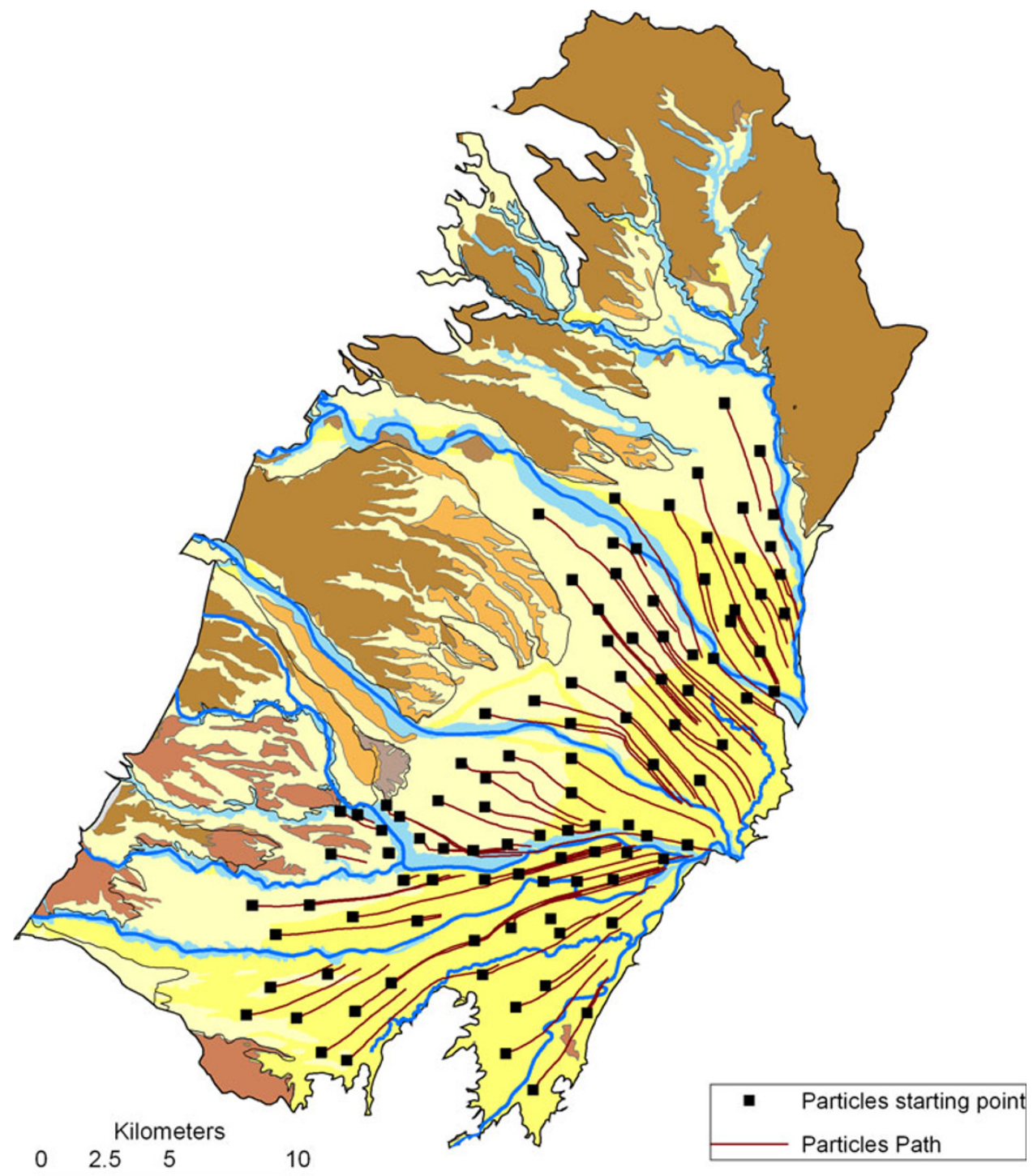

upper tributaries of the Tukipo such as Mangatewai are gaining and losing, and the Avoca is losing.

\section{Makaretu Stream}

Makaretu Stream drains the hill country of the southern Ruataniwha Basin and is fed predominantly by surface runoff. The gauging results show the flow in Makaretu is stable upstream and starts losing to the confluence with Tukipo. Model results show that it loses and gains upstream at small rates (not picked up by concurrent gauging), and start gaining just before where it meets the Tukipo.

Porangahau and Maharakeke streams are small and have dry reaches upstream. These streams start gaining water from the aquifer downstream just before where they meet.

\section{Conclusion}

Characterisation of aquifer-river interaction is important for water resources management, especially in sensitive catchments, where this interaction is high. This enables an integrated water resources management, where groundwater and surface waters are managed as one source. Different approaches have been developed and used to understand this interaction.

Integrated surface-groundwater numerical modelling has been used to understand the aquifer/river interaction in the Ruataniwha Basin, Hawke's Bay, New Zealand. The advantage of integrated surface-groundwater modelling is that it is a inexpensive tool, compared with other approaches, and provides fairly good and accurate results. 
The finite difference-based MODFLOW model has been used with the Stream Package SFR1. Historical gauging data over the period from 1990 to 2010 has been used in the model for stream routing. Recent concurrent gauging field work has been undertaken to support and validate the model results.

In total, 12 rivers and streams have been simulated consequentially with the aquifer system in the basin. Results of the numerical model show a good agreement with the concurrent gauging. A high correlation between simulated and measured flow at the basin outlet has been achieved.

Model results also show that rivers gain from the aquifer system is more than river losses. Spatially, losses and gains vary from one river reach to another. In general, rivers slightly gain upstream, then start losing and finally gain again as they exit the basin. This is consistent with the concurrent gauging results.

The results of this study may help the establishment of integrated water resources management in the Ruataniwha Basin. Rivers in the upper part of the basin are less vulnerable to drought, as the river-aquifer interaction is weak. The most fragile ecosystem occurs around lower part of the basin, where the Waipawa River dries up every summer. By understanding the gain-loss relationship, rationing of groundwater abstraction in certain areas, like the one between lower Waipawa and lower Tukituki, may help prevent future dry-reach phenomena. It is also useful to allocate surface water based on the river-aquifer relationships, that is, allocating less water in the losing parts of the rivers.

Open Access This article is distributed under the terms of the Creative Commons Attribution License which permits any use, distribution, and reproduction in any medium, provided the original author(s) and the source are credited.

\section{References}

Anderson M (2005) Heat as a ground water tracer. Ground Water 43:951-968

Ayenew T, Kebede S, Alemyahu T (2008) Environmental isotopes and hydrochemical study applied to surface water and groundwater interaction in the Awash River basin. Hydrol Process 22:1548-1563

Baalousha H (2010) Ruataniwha basin transient groundwater-surface water flow model. Hawke's Bay Regional Council. Technical Report EMT 10/30

Barlow J, Coupe R (2009) Use of heat to estimate streambed fluxes during extreme hydrologic events. Water Resour Res. doi:10.1029/2007WR006121
Constantz J (2008) Heat as a tracer to determine streambed water exchanges. Water Resour Res. doi:10.1029/2008WR006996

Francis D (2001) Subsurface geology of the Ruataniwha Plains and relation to hydrology. Technical report. Geological Research Ltd, Lower Hutt. New Zealand

Gooddy D, Darling W, Abesser C, Lapworth D (2006) Using chlorofluorocarbons (CFCs) and sulphur hexafluoride $\left(\mathrm{SF}_{6}\right)$ to characterise groundwater movement and residence time in a lowland Chalk catchment. J Hydrol 330:44-52

Hatch C, Fisher A, Revenaugh J, Constantz J, Ruehl C (2006) Quantifying surface water-groundwater interactions using time series analysis of streambed thermal records: method development. Water Resour Res. doi:10.1029/2005WR004787

Hawke's Bay Regional Council (2003) Ruataniwha Plains water resources investigations. Technical Report. HBRC Plan Number 3254

Krause S, Bronstert A, Zehe E (2007) Groundwater-surface water interactions in a North German lowland floodplain-implications for the river discharge dynamics and riparian water balance. J Hydrol 347:404-417

Kumar M, Al Ramanathan, Keshari A (2009) Understanding the extent of interactions between groundwater and surface water through major ion chemistry and multivariate statistical techniques. Hydrol Process 23:297-310

Lapham W (1989) Use of temperature profiles beneath streams to determine rates of ground-water flow and hydraulic conductivity. US Geological Survey water supply paper 2337

Lowry C, Walker J, Hunt R, Anderson M (2007) Identifying spatial variability of groundwater discharge in a wetland stream using a distributed temperature sensor. Water Resour Res. doi:10.1029/ 2007WR006145

McDonald MG, Harbaugh AW (1988) A modular three-dimensional finite-difference ground-water flow model. US Geological Survey Techniques of Water Resources Investigations Report Book 6, Chap A1, p 528

Négrel Ph, Petelet-Girauda E, Barbiera J, Gautier E (2003) Surface water-groundwater interactions in an alluvial plain: chemical and isotopic systematic. J Hydrol 277:248-267

Parkin G, Birkinshaw S, Younger P, Rao Z, Kirk S (2007) A numerical modelling and neural network approach to estimate the impact of groundwater abstractions on river flows. J Hydrol 339: $15-28$

Prudic DE, Konikow LF, Banta ER (2004) A new stream-flow routing (SFR1) package to simulate stream-aquifer interaction with MODFLOW-2000: U.S. Geological Survey Open-File Report 2004-1042, $95 \mathrm{p}$

Rassam D, Pagendam D, Hunter H (2008) Conceptualisation and application of models for groundwater surface water interactions and nitrate attenuation potential in riparian zones. Environ Model Softw 23:859-875

Schlumberger Water Services (2008) Visual MODFLOW Premium 4.3. User's Manual

Winter T, Harvey J, Franke O, Alley W (1998) Ground water and surface water. A Single Resource. US Geological Survey Circular 1139. Denver, Colorado. Technical report 